\title{
First space-borne measurements of methanol inside aged southern tropical to mid-latitude biomass burning plumes using the ACE-FTS instrument
}

\author{
G. Dufour ${ }^{1}$, C. D. Boone ${ }^{2}$, C. P. Rinsland ${ }^{3}$, and P. F. Bernath ${ }^{2}$ \\ ${ }^{1}$ Laboratoire de Météorologie Dynamique/Institut Pierre Simon Laplace, Palaiseau, France \\ ${ }^{2}$ Department of Chemistry, University of Waterloo, Ontario, Canada \\ ${ }^{3}$ NASA Langley Research Center, Hampton, VA, USA
}

Received: 25 January 2006 - Published in Atmos. Chem. Phys. Discuss.: 18 May 2006

Revised: 26 July 2006 - Accepted: 4 August 2006 - Published: 21 August 2006

\begin{abstract}
First measurements from space of upper tropospheric and lower stratospheric methanol profiles within aged fire plumes are reported. Elevated levels of methanol at $0-45^{\circ} \mathrm{S}$ from 30 September to 3 November 2004 have been measured by the high resolution infrared spectrometer ACEFTS onboard the SCISAT satellite. Methanol volume mixing ratios higher than $4000 \mathrm{pptv}$ are detected and are strongly correlated with other fire products such as $\mathrm{CO}, \mathrm{C}_{2} \mathrm{H}_{6}$, and HCN. A sensitivity study of the methanol retrieval, accounting for random and systematic contributions, shows that the retrieved methanol profile for a single occultation exceeds $100 \%$ error above $16.5 \mathrm{~km}$, with an accuracy of about $20 \%$ for measurements inside polluted air masses. The upper tropospheric enhancement ratio of methanol with respect to $\mathrm{CO}$ is estimated from the correlation plot between methanol and $\mathrm{CO}$ for aged tropical biomass burning plumes. This ratio is in good agreement with the ratio measured in the free troposphere (up to $12 \mathrm{~km}$ ) by recent aircraft studies and does not suggest any secondary production of methanol by oxidation in aged biomass burning plumes.
\end{abstract}

\section{Introduction}

Biomass burning is a major source of anthropogenic air pollution (Crutzen and Andreae, 1990). Intense fires occurring during the dry season of each hemisphere in the tropics are the main source of biomass burning products in the atmosphere on a global scale (Hao and Liu, 1994). In addition to emissions of large quantities of $\mathrm{CO}_{2}, \mathrm{CO}$ and aerosols, many other organic compounds are emitted at significant levels (Yokelson et al., 1999; Holzinger at al., 1999; Goode et

Correspondence to: G. Dufour

(gaelle.dufour@1md.polytechnique.fr) al., 2000; Andreae and Merlet, 2001). Methanol $\left(\mathrm{CH}_{3} \mathrm{OH}\right)$ is one of these chemicals.

After methane, methanol is the most abundant organic molecule in the troposphere (Jacob et al., 2005). Typical background concentrations are 400-1000 pptv in clean air in the boundary layer (Lewis et al., 2005) or in the free troposphere (Singh et al., 1995). The atmospheric lifetime is about 16 days in the free troposphere (Singh et al., 1995) due primarily to $\mathrm{OH}$ oxidation to produce formaldehyde. $\mathrm{CH}_{3} \mathrm{OH}$ thus has an important effect on the oxidative capacity of the atmosphere.

The primary source of atmospheric methanol is the growth ( $\sim 60 \%)$ and decay $(\sim 10 \%)$ of plants, with biomass burning providing an additional $10 \%$ or so of the budget. The oxidation of methane (and other hydrocarbons) can also produce methanol primarily via the self reaction of the $\mathrm{CH}_{3} \mathrm{OO}$ radicals to form $\mathrm{CH}_{3} \mathrm{OH}$ and $\mathrm{H}_{2} \mathrm{CO}$, which accounts for another $20 \%$. The direct anthropogenic contribution (e.g., solvent emission) is just a few percent. These numbers are all based on the recent budget of Jacob et al. (2005) and the values have considerable uncertainty, and they differ substantially from previous budgets (Singh et al., 2000; Heikes et al., 2002; Galbally and Kirstine, 2002; von Kuhlmann et al., 2003a, b). Methanol is involved in $\mathrm{HO}_{\mathrm{x}}$ chemistry because the reaction with $\mathrm{OH}$ forms the $\mathrm{CH}_{3} \mathrm{O}$ and $\mathrm{H}_{2} \mathrm{COH}$ radicals, which rapidly react with $\mathrm{O}_{2}$ to give $\mathrm{HO}_{2}$ and $\mathrm{H}_{2} \mathrm{CO}$. Formaldehyde chemistry produces additional $\mathrm{HO}_{2}$ radicals and $\mathrm{CO}$ so methanol is a significant source of both $\mathrm{H}_{2} \mathrm{CO}$ and $\mathrm{CO}$ (Palmer et al., 2003). The majority of measurements of atmospheric methanol concentrations are performed in surface air (Heikes et al., 2002; Lewis et al., 2005). Recent aircraft campaigns have allowed the measurement of a few methanol profiles in the free troposphere up to $12 \mathrm{~km}$ (e.g., Singh et al., 2001, 2004).

Published by Copernicus GmbH on behalf of the European Geosciences Union. 


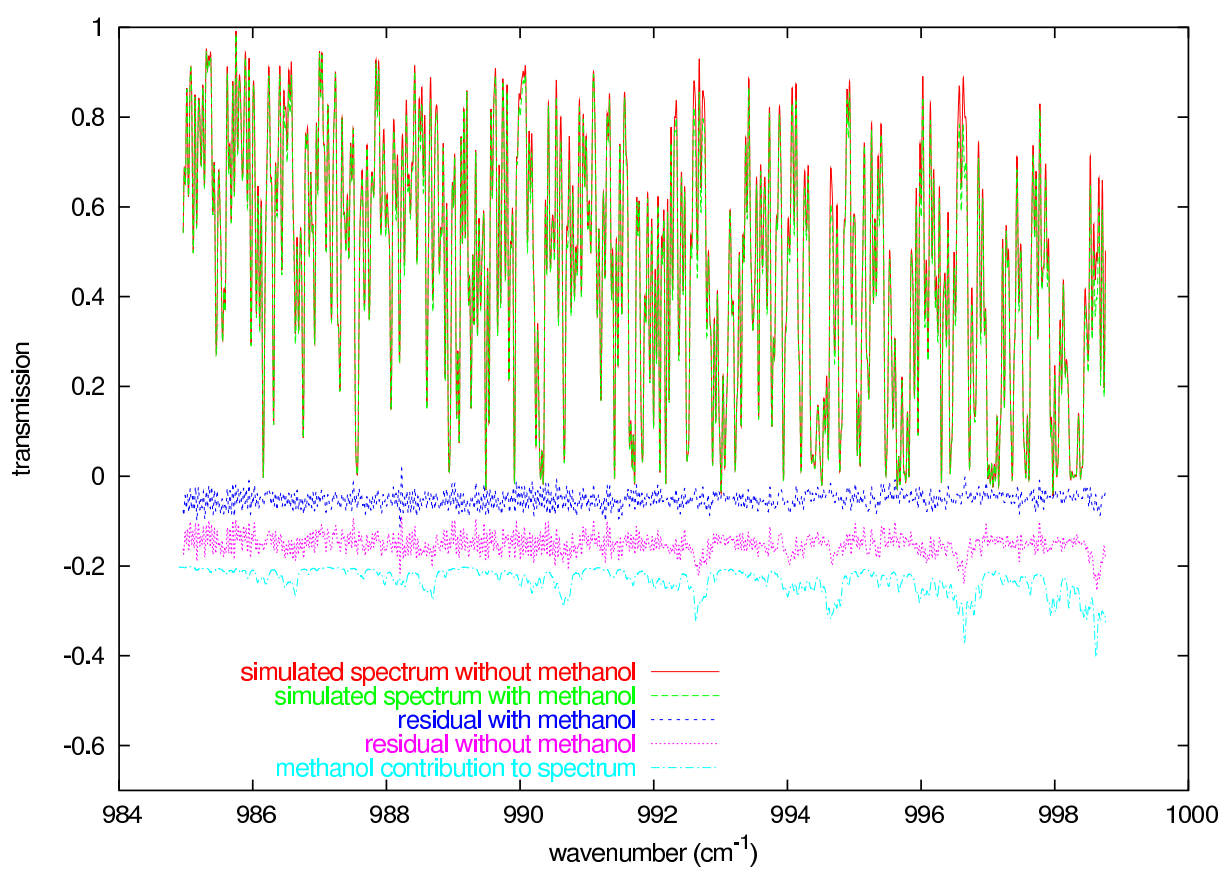

Fig. 1. Simulated spectra with methanol included or excluded in the calculation. The corresponding residuals (observed - calculated) and the computed contribution of $\mathrm{CH}_{3} \mathrm{OH}$ to the spectrum using the retrieved vmr are plotted (shifted downwards for clarity).

We report the first methanol profile measurements in the upper troposphere and the lower stratosphere (UTLS) from space. Volume mixing ratios (vmrs) higher than $4000 \mathrm{pptv}$ have been measured by the space-borne instrument ACEFTS inside biomass burning plumes already detected by this instrument in southern lower to mid-latitudes during October 2004 (Rinsland et al., 2005a). After discussing the reliability of the retrieval, methanol profiles are compared to the corresponding $\mathrm{CO}$ profiles and the results are discussed.

\section{ACE-FTS measurements and retrieval}

\subsection{Evidence of a methanol contribution to the spectra}

The Atmospheric Chemistry Experiment (ACE) makes solar occultation measurements and has a global coverage from approximately $85^{\circ} \mathrm{N}$ to $85^{\circ} \mathrm{S}$ with a majority of measurements over the Arctic and the Antarctic (Bernath et al., 2005). However, the orbital coverage yields opportunities to study tropical events in the mid and upper troposphere such as biomass burning plumes (Rinsland et al., 2005a) but for limited time spans. The primary ACE instrument is a high resolution $\left(0.02 \mathrm{~cm}^{-1}\right)$ Fourier transform spectrometer (ACEFTS) operating between 750 and $4400 \mathrm{~cm}^{-1}$. Vertical profiles of temperature, pressure and various atmospheric constituents are retrieved from the ACE-FTS spectra recorded at a series of tangent heights using a global fit approach coupled with a Levenberg-Marquardt non-linear least squares method (Boone et al., 2005). For the occultations considered in the current study, the tangent height spacing ranges between 0.5 and $2.5 \mathrm{~km}$, but the altitude resolution of the retrieved profiles is ultimately limited by the field of view of the ACE-FTS instrument, which gives an altitude resolution of 3-4 km. Spectroscopic parameters are taken from the HITRAN 2004 line list (Rothman et al., 2005). Molecular absorption lines are fitted in selected microwindows to determine temperature and volume mixing ratio profiles. A set of microwindows is determined for each target species and is optimized to reduce the impact of interfering species, and to retrieve the vertical profile over the broadest possible altitude range. The retrieval algorithm version currently used in the ACE-FTS retrieval process is version 2.2. However, we use a research version of the algorithm, which can include isotopologues as interfering species during the fitting process independently of the main isotopologue, for the methanol retrieval.

The strongest absorption band of methanol in the infrared spectral region is the band at $10 \mu \mathrm{m}$ (http://vpl.ipac.caltech. edu/spectra/methanol.htm). Spectroscopic data of this band have been recently included in the HITRAN database based on the work of $\mathrm{Xu}$ et al. (2004). The empirical line list at $10 \mu \mathrm{m}$ arises mainly from the fundamental CO-stretching mode $v_{8}$ at $1033 \mathrm{~cm}^{-1}$. Methanol is retrieved between 7 and $35 \mathrm{~km}$ using a large spectral window $\left(984.9-998.7 \mathrm{~cm}^{-1}\right)$. Most of the strongest lines in this window are lines of the $v_{8}$ and $v_{8}+v_{12}-v_{12}$ bands. A small percentage of the lines belong to the $v_{8}+2 v_{12}-2 v_{12}$ and $v_{7}$ bands. The main 
Table 1. Sensitivity study of the methanol retrieval for measurements inside tropical biomass burning plumes (October 2004) ${ }^{\mathrm{a}}$.

\begin{tabular}{cccccccccccccc}
\hline $\begin{array}{c}\text { Altitude } \\
\text { km }\end{array}$ & $\begin{array}{c}\text { Mean } \\
\text { vmr }\end{array}$ & $\begin{array}{c}\text { Meas. } \\
\text { noise }\end{array}$ & $\begin{array}{c}\text { Spectr. } \\
\text { Data }^{b}\end{array}$ & Pointing $^{\mathrm{c}}$ & $\mathrm{T}^{\mathrm{d}}$ & $\mathrm{ILS}^{\mathrm{e}}$ & $\mathrm{CO}_{2}^{\mathrm{f}}$ & $\mathrm{H}_{2} \mathrm{O}^{\mathrm{g}}$ & $\mathrm{NH}_{3}^{\mathrm{h}}$ & $\mathrm{C}_{2} \mathrm{H}_{4}^{\mathrm{h}}$ & $\mathrm{OO}^{17} \mathrm{O}^{\mathrm{i}}$ & $\mathrm{O}^{17} \mathrm{OO}^{\mathrm{i}}$ & $\begin{array}{c}\text { Total } \\
\text { Error }^{\mathrm{j}}\end{array}$ \\
\hline 8.5 & 1576 & 319 & 204 & 87 & 51 & 0.7 & 5 & 8 & 11 & 6 & 0.7 & 0.3 & $392(25)$ \\
10.5 & 1767 & 240 & 237 & 102 & 57 & 0.6 & 4 & 5 & 6 & 4 & 0.6 & 0.3 & $357(20)$ \\
12.5 & 1292 & 263 & 169 & 77 & 38 & 0.8 & 3 & 3 & 4 & 2 & 0.7 & 0.2 & $324(25)$ \\
14.5 & 749 & 276 & 98 & 55 & 16 & 0.8 & 2 & 2 & 1 & 0.7 & 0.5 & 0.3 & $298(40)$ \\
16.5 & 296 & 341 & 40 & 48 & 14 & 2 & 2 & 2 & 0.5 & 0.6 & 0.4 & 0.4 & $347(117)$ \\
18.5 & 214 & 392 & 26 & 39 & 21 & 4 & 2 & 1 & 0.8 & 0.8 & 1 & 1 & $395(185)$ \\
20.5 & 221 & 470 & 33 & 76 & 33 & 10 & 2 & 2 & 0.6 & 1 & 3 & 3 & $479(217)$ \\
\hline
\end{tabular}

\footnotetext{
a The mean methanol vmr values and the errors are in pptv.

${ }^{b}$ Based on spectroscopic uncertainty of $15 \%$ for methanol as given in the HITRAN2004 database.

${ }^{\mathrm{c}}$ Based on a tangent height uncertainty of $150 \mathrm{~m}$.

$\mathrm{d}$ Based on a temperature uncertainty of $2 \mathrm{~K}$.

e Since the ILS is parameterized, uncertainty in the ILS is induced by perturbing the field of view by $5 \%$.

${ }^{\mathrm{f}}$ Based on an uncertainty of $1 \%$.

$\mathrm{g}$ Based on early validation results (10\%) (McHugh et al., 2005).

$\mathrm{h}$ Based on a global uncertainty of $20 \%$ (including spectroscopic and climatological uncertainties).

${ }^{\mathrm{i}}$ Based on a variation of $5 \%$ of the vmr values compared to the main isotope.

$\mathrm{j}$ The effective total error (see text) is given in absolute (pptv) and in relative (\%) units (numbers in parentheses).
}

interfering species in the spectral range used are $\mathrm{O}_{3}$ and its minor isotopologues, $\mathrm{CO}_{2}, \mathrm{H}_{2} \mathrm{O}, \mathrm{NH}_{3}$, and $\mathrm{C}_{2} \mathrm{H}_{4}$. The isotopologues 1,2 and $3\left(\mathrm{OOO}, \mathrm{OO}^{18} \mathrm{O}\right.$ and $\mathrm{O}^{18} \mathrm{OO}$, respectively) of ozone are fitted simultaneously with methanol while the other interfering species are fixed to their previously retrieved values for $\mathrm{H}_{2} \mathrm{O}$ (version 2.2) and to their climatological values for $\mathrm{CO}_{2}, \mathrm{NH}_{3}$, and $\mathrm{C}_{2} \mathrm{H}_{4}$. The fractionation of isotopologues 4 and $5\left(\mathrm{OO}^{17} \mathrm{O}\right.$ and $\mathrm{O}^{17} \mathrm{OO}$, respectively) of ozone are fixed using the normal isotopic abundances to the values of the main isotope previously retrieved. Data from the same time spans used by Rinsland et al. (2005a) (30 September-6 October 2004 and 26 October-3 November 2004) were analysed. It is worth noting that $\mathrm{NH}_{3}$ and $\mathrm{C}_{2} \mathrm{H}_{4}$ are short-lived biomass burning emission products that could then be also enhanced during fire events and that could have significant contribution to the spectrum (Rinsland et al., 2005b). However, Rinsland et al. (2005a) show that the fire plumes detected by ACE-FTS in October 2004 are aged plumes (up to one week): only species with a larger lifetime are then detectable. Moreover, we checked that considering climatological vmr values for $\mathrm{NH}_{3}$ and $\mathrm{C}_{2} \mathrm{H}_{4}$ does not lead to features in the residuals (observed-calculated) of the spectra. Figure 1 shows the comparison between a simulated spectrum without accounting for the contribution of $\mathrm{CH}_{3} \mathrm{OH}$ and the same spectrum including the methanol contribution (the spectrum used corresponds to the spectrum at the maximum of an enhanced profile of methanol). The corresponding residuals (observed - calculated) are also plotted as well as the methanol contribution to the spectrum (shifted down) assuming a vmr value equal to the value retrieved for this spectrum $(\sim 3900 \mathrm{pptv})$. The sharp features in the residu- als when methanol is not included are similar in position and shape to the methanol contribution to the spectrum. Furthermore, the residuals when methanol is included in the calculated spectrum are reduced substantially (Fig. 1, pink curve), showing a clear contribution due to methanol.

\subsection{Sensitivity of the retrieval to different error sources}

ACE-FTS spectra are inverted to vertical profiles of atmospheric state variables, $\boldsymbol{x}$, using an iterative nonlinear least squares fitting procedure as described originally by Levenberg (1944) and Marquardt (1963) in a global fit approach:

$\boldsymbol{x}_{i+1}=\boldsymbol{x}_{i}+\left(\mathbf{K}^{T} \mathbf{S}_{y}^{-1} \mathbf{K}+\lambda \mathbf{I}\right)^{-1} \mathbf{K}^{T} \mathbf{S}_{y}^{-1}\left(\boldsymbol{y}-\boldsymbol{F}\left(\boldsymbol{x}_{i}, \boldsymbol{b}\right)\right)$,

in which $\boldsymbol{y}$ is the vector of measurements (that includes measurements of all the tangent altitudes), $\boldsymbol{F}$ the radiative transfer model, $\boldsymbol{b}$ the forward model parameter vector, $i$ the iteration number, $\mathbf{K}$ the Jacobian of $\boldsymbol{F}$ with respect to $\boldsymbol{x}, \lambda$ is the Levenberg-Marquardt weighting factor and $\mathbf{S}_{y}$ the error covariance matrix of the measurements that is assumed to be diagonal.

The $1 \sigma$ statistical error in the case of a LevenbergMarquardt method is:

$\sigma_{m}\left(x_{j}\right)=\sqrt{\left(\mathbf{K}^{T} \mathbf{S}_{y}^{-1} \mathbf{K}\right)_{j j}^{-1}}$.

This error that we name "measurement noise error" in Table 1 is the error usually reported by version 2.2. However, considering only the statistical error of the fitting does not 

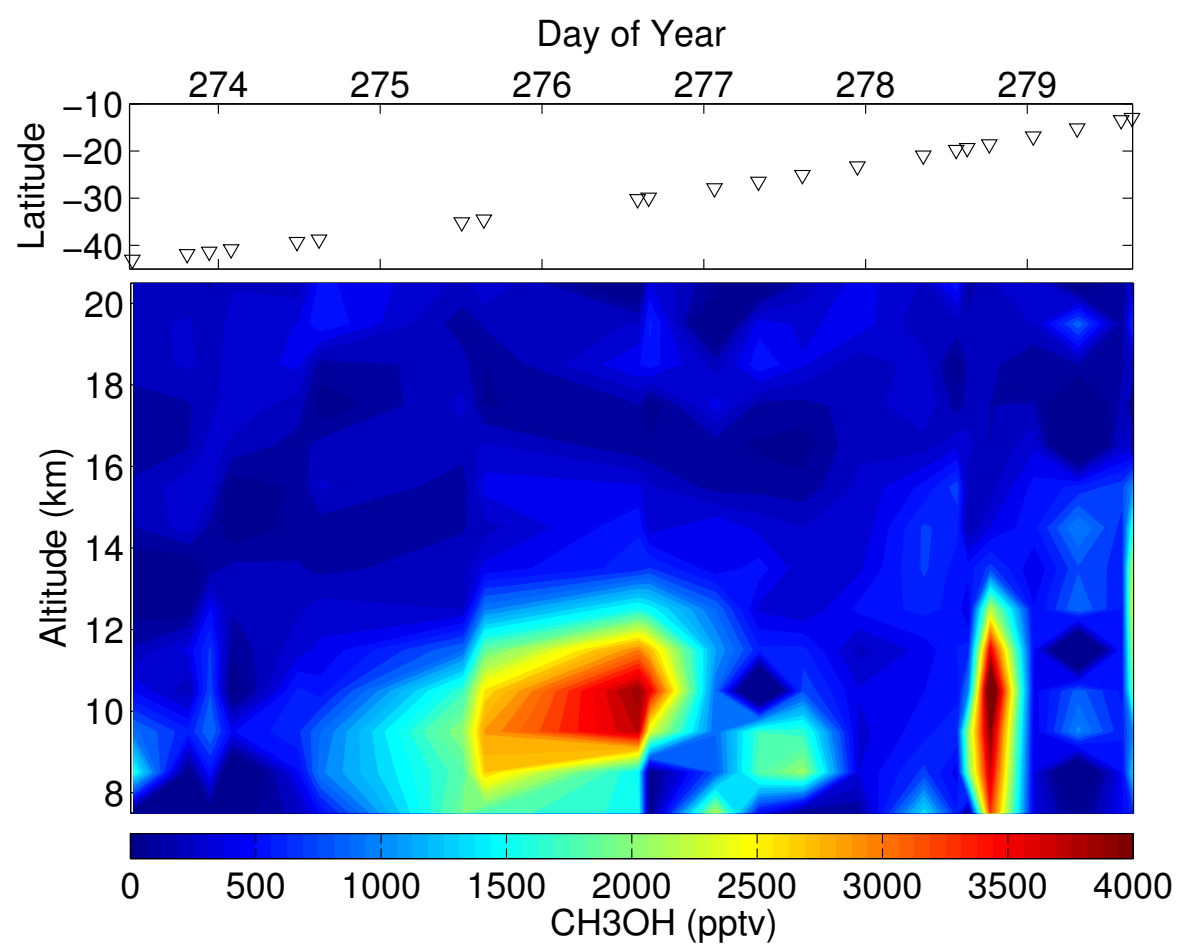

Fig. 2. Time series of ACE-FTS measurements of methanol for sunsets between 30 September (273, Julian day) and 6 October 2004 (279, Julian day). The latitude and the time of each individual measurement are shown at the top of the panel.

account for errors induced by uncertain parameters. To estimate the sensitivity of the methanol retrieval to each uncertain parameter $b_{j}$, the retrieval was performed by perturbing each parameter by $1 \sigma$ of its assumed uncertainty. A scalar perturbation of the entire profile is applied in the case of parameters described by a profile. This approach maximizes the errors and then gives a realistic estimation of them. The error induced in the retrieved profile is then:

$\Delta \boldsymbol{x}_{j}=\boldsymbol{x}\left(b_{j}\right)-\boldsymbol{x}\left(b_{j}+\Delta b_{j}\right)$

Error sources accounting for uncertainties in temperature, tangent altitude pointing, $\mathrm{CH}_{3} \mathrm{OH}$ spectroscopic data, instrumental line shape (ILS), and mixing ratios of the main interfering species $\left(\mathrm{CO}_{2}, \mathrm{H}_{2} \mathrm{O}, \mathrm{NH}_{3}, \mathrm{C}_{2} \mathrm{H}_{4}\right.$ and isotopologues 4 and 5 of ozone) are considered. The effects of uncertainties in the baseline of the spectra, spectral shifts and isotopologues 1, 2 and 3 of ozone are not included in this sensitivity study because these parameters are fitted simultaneously with methanol. Table 1 presents the sensitivity results from the average of the individual results obtained for each enhanced occultation. The total error in the last column is an effective total error as the standard deviations given for each uncertain parameter are the mean of the individual standard deviations of each occultation. Considering the mean standard deviations and the effective total error gives a better representation of the sensitivity of the methanol retrieval to uncertainties rather than considering just a single occultation.
We also checked several individual occultations to verify that the average sensitivities were representative of the entire profile, especially near the maximum. The methanol retrieval is mainly sensitive to uncertainties in the tangent height determination, in the temperature and in the spectroscopic data of methanol. Sensitivity to pointing and temperature increases with altitude when $\mathrm{CH}_{3} \mathrm{OH}$ vmr decreases whereas sensitivity to spectroscopic data stays constant with respect to altitude (about 13\%, as expected). The sensitivity of the retrieval to uncertainties in the ILS and interfering species is less than $1 \%$ on average for all the altitudes between 8.5 and $20.5 \mathrm{~km}$. The effective total error deduced has a minimum at the maximum of the profile and represents about $20 \%$ of the vmr value and increases with the altitude above the maximum to reach relative values greater than $100 \%$ above $16.5 \mathrm{~km}$. Therefore, in the following we only consider retrieval results for methanol up to $16.5 \mathrm{~km}$. Above this altitude, the reliability of the profiles is poor, but the vmr values retrieved are close to zero as expected.

\section{Results and discussion}

The ACE-FTS sampled the southern low to mid-latitudes during two time spans, between 30 September (273 in Julian day) and 6 October 2004 (279), and between 25 October (298) and 3 November 2004 (307). The tropopause 


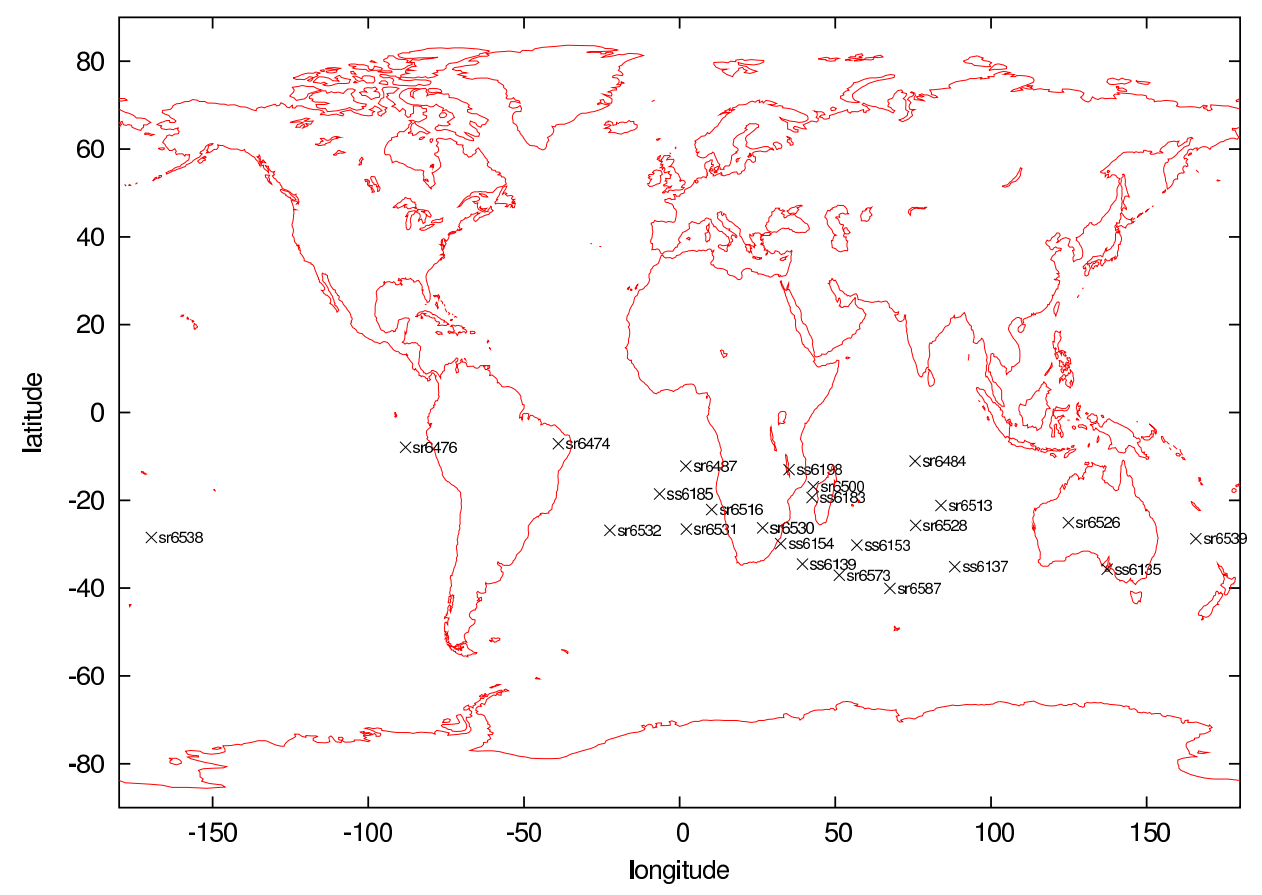

Fig. 3. Location of ACE-FTS occultations showing enhanced levels of methanol during October 2004.

height (derived from NCEP calculations) during this period varies between 9 and $17 \mathrm{~km}$ (Rinsland et al., 2005a , Fig. 1). The time series obtained for the first period is plotted in Fig. 2. The latitude of the individual measurements is indicated at the top panel. During the first time period, measurements correspond to sunsets whereas they correspond to sunrises during the second time period. Methanol vmrs as high as $(4594 \pm 225)$ pptv at $10.5 \mathrm{~km}$ and $(2836 \pm 461) \mathrm{pptv}$ at $13.5 \mathrm{~km}$ are measured on 5 October 2004 and on 25 October 2004, respectively. Methanol enhancements decrease between the two time periods corresponding to the decrease in the intensity of the fire season in the Southern Hemisphere. Figure 3 shows the distribution of the ACE occultations in the southern tropical to mid-latitudes for which enhanced methanol levels have been detected during October 2004. These occultations are similar to the occultations for which Rinsland et al. (2005a) show enhancements of other fire products such as $\mathrm{CO}, \mathrm{HCN}$ and $\mathrm{C}_{2} \mathrm{H}_{6}$.

Figure 4 shows an example of a methanol profile retrieved from the sunset occultation ss6153 measured on 3 October 2004 at $30.2^{\circ} \mathrm{S}$ and $56.9^{\circ} \mathrm{E}$, and showing the largest enhancement of $\mathrm{CO}, \mathrm{HCN}$ and $\mathrm{C}_{2} \mathrm{H}_{6}$ during this period (Rinsland et al., 2005a). Methanol vmr values of about $4000 \mathrm{pptv}$ are measured around the maximum at $10.5 \mathrm{~km}$. The CO profile retrieved for the same occultation is plotted for comparison and the shape is similar. The maximum of the methanol profile is slightly higher than the maximum of the $\mathrm{CO}$ profile, but this is likely due to a sampling effect. We also analysed occultations outside the biomass burning plumes for the same time periods (beginning and end of October 2004) and the same latitude band $\left(0-45^{\circ} \mathrm{S}\right)$. An example of a background profile is also plotted in Fig. 4 for comparison. It is worth noting that vmr values measured by ACE-FTS for the background cases in the southern low to mid-latitudes agree with values measured from aircraft by Singh et al. (2004) between 8 and $12 \mathrm{~km}$ above the Pacific.

Figure 5 shows a correlation plot of methanol versus $\mathrm{CO}$ for all of the profiles between 8.5 and $16.5 \mathrm{~km}$ measured inside biomass burning plumes during October 2004 in the latitude band $0-45^{\circ} \mathrm{S}$. Methanol vmrs and CO vmrs are strongly correlated for measurements inside polluted air masses: the correlation coefficient derived from the plot is 0.91. For comparison, the correlation coefficient deduced from the background measurements performed during the same time period and in the same latitude band is about 0.75 . The slope of the linear fit (Fig. 5) for measurements inside biomass burning plumes, defined as $\Delta\left(\mathrm{CH}_{3} \mathrm{OH}\right) / \Delta(\mathrm{CO})$, is $(16.4 \pm 0.5) \mathrm{pptv} / \mathrm{ppbv}$. Since only measurements in polluted air masses are considered, this value can be compared to the enhancement ratios reported in many studies (e.g. Singh et al., 2004, Christian et al., 2003, Holzinger et al., 2005). Deriving the enhancement ratio by using simultaneously the data between 8.5 and $16.5 \mathrm{~km}$ for all the plumes detected implicitly implies that the ratio is independent of altitude inside the plume and that all the plumes sampled in October 2004 have the same enhancement ratio. This last assumption is difficult to avoid because the ACE-FTS sampled transported air masses, and the injection location and the fire type are difficult to identify clearly even using back trajectory calculations. The first assumption is reasonable in our case because 


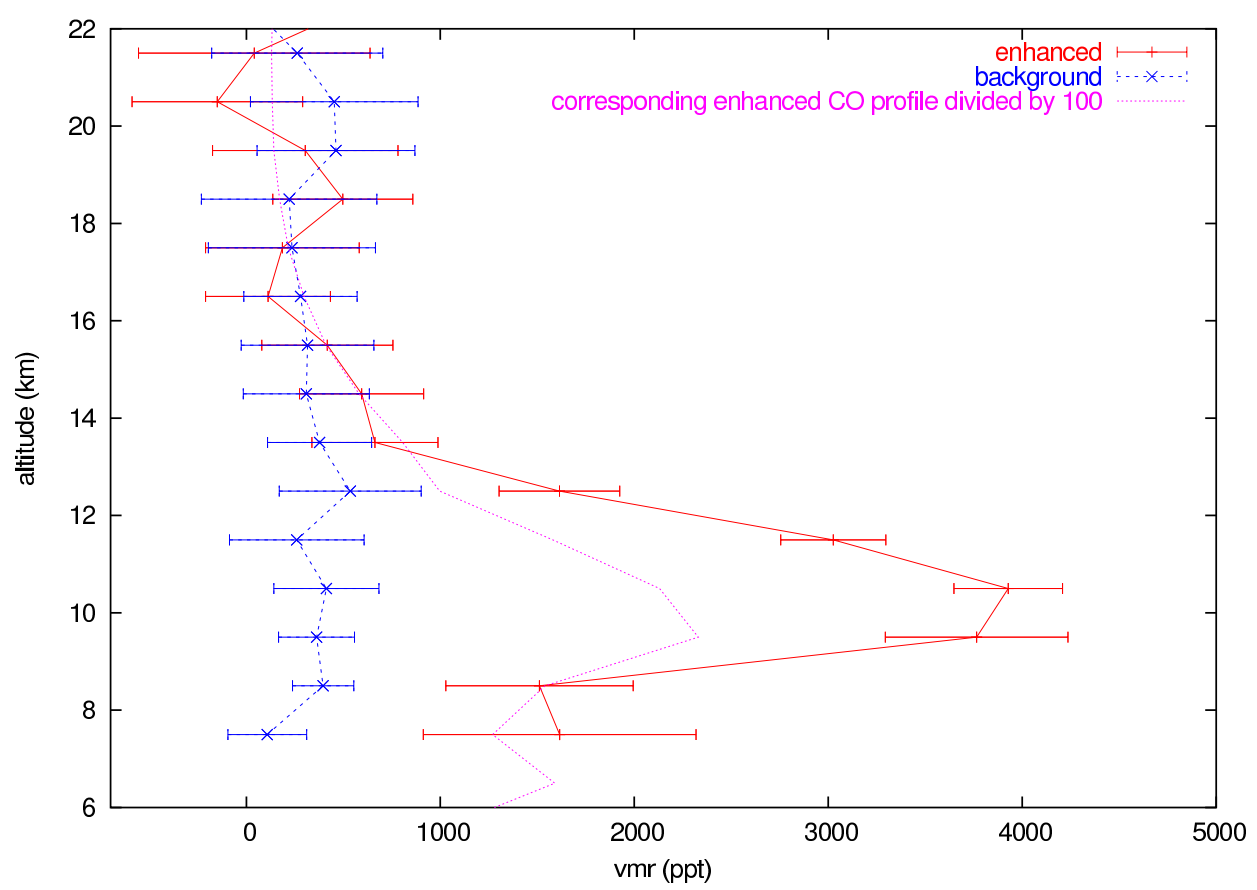

Fig. 4. Enhanced methanol profile retrieved from the sunset occultation ss6153 measured on 3 October 2004 at $30.2^{\circ} \mathrm{S}$ and $56.9^{\circ} \mathrm{E}$ (tropopause height $\approx 14.8 \mathrm{~km}$ ). The CO profile retrieved for the same occultation is plotted for comparison as well as an example of background profile of methanol retrieved during the same time period and in the same latitude band (tropopause height $\approx 10.4 \mathrm{~km}$ ). Errors correspond to the $1 \sigma$ error defined in Eq. (2).

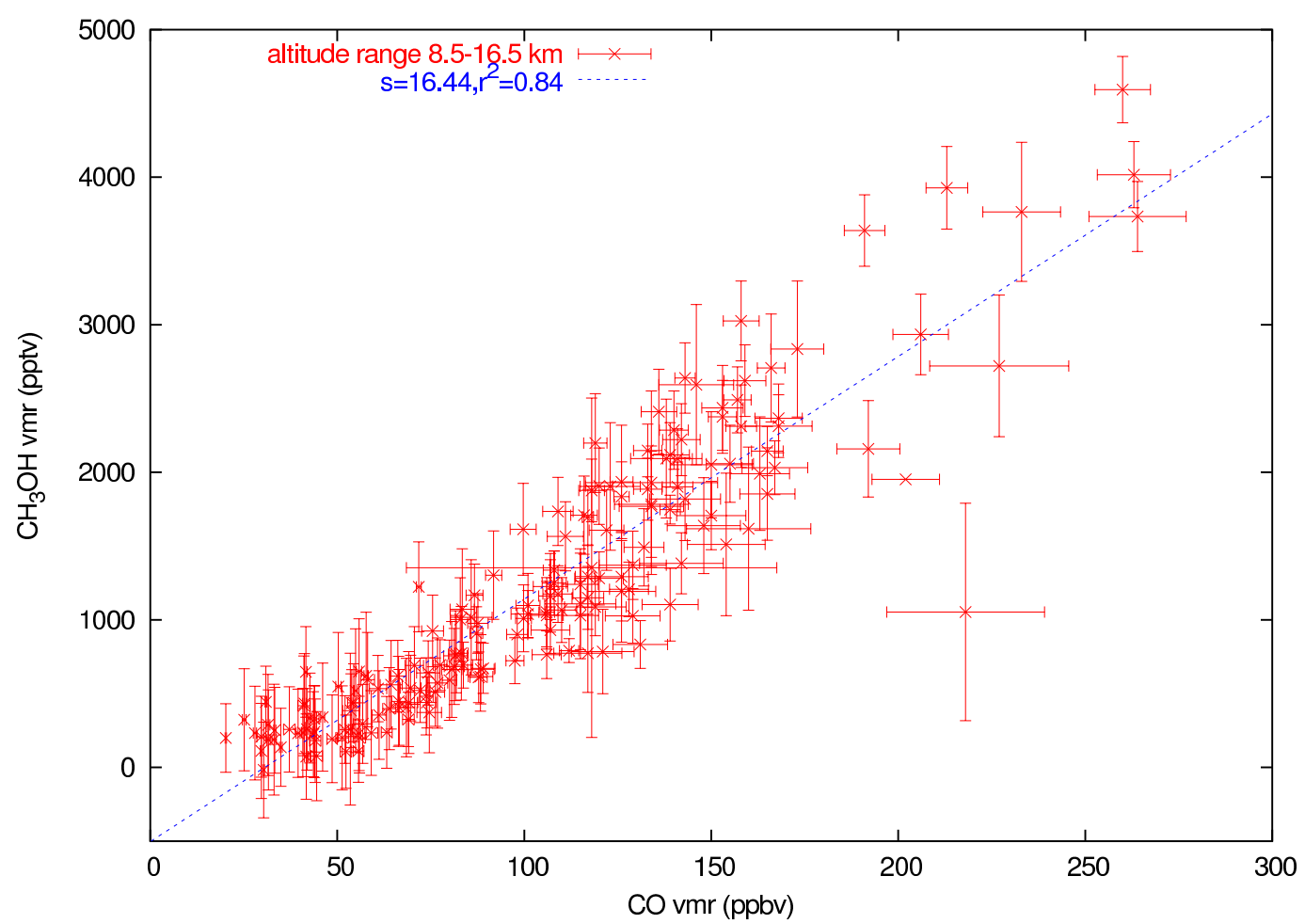

Fig. 5. Correlation plot of methanol and carbon monoxide vmrs measured between 8.5 and $16.5 \mathrm{~km}$ inside aged biomass burning plumes from 30 September to 3 November 2004 at $0-45^{\circ} \mathrm{S}$ latitude and the linear fit results. Errors correspond to the $1 \sigma$ error defined in Eq. (2). 
the ACE-FTS samples air masses in the southern tropical and middle latitudes where the biogenic emissions of methanol (typically from plant growth) are negligible compared to fire emissions.

Singh et al. (2004) report a mean enhancement ratio of $16 \mathrm{pptv} / \mathrm{ppbv}$ in the free troposphere for fire plumes from Southeast Asia measured over the Pacific. Christian et al. (2003) find a mean value of $24 \mathrm{pptv} / \mathrm{ppbv}$ for Indonesian fuels. Holzinger et al. (2005) report a higher mean value of $38 \mathrm{pptv} / \mathrm{ppbv}$ over the Mediterranean. Yokelson et al. (2003) provide an estimation of fire-average initial emission ratio for methanol of (14.4 \pm 3.0$) \mathrm{pptv} / \mathrm{ppbv}$. This emission ratio is the average of initial emission ratios measured directly above different kinds of savanna fires (pure grassland, grassland with some brush and small trees, open forest with a grass/brush understory). Although the fire plumes sampled by the ACE-FTS during October 2004 were aged for up to 7 days (Rinsland et al., 2005a), the enhancement ratio derived from our measurements is comparable with the initial emission ratio derived by Yokelson et al. (2003), and also in agreement with the value of Singh et al. (2004), who also measured aged plumes. Our enhancement ratio, however, is less than half of the value of Holzinger et al. (2005), who sampled an aged fire plume (2-3 days old) in which secondary production took place. There is thus no evidence from our measurements that secondary production of methanol proceeds in the air masses sampled by the ACEFTS. It is important to note that until now methanol profiles have been measured only by aircraft in situ and these measurements have all been below $12 \mathrm{~km}$ in altitude. The ability of ACE-FTS to retrieve methanol profiles above the tropopause is a significant improvement.

\section{Summary and conclusion}

In this paper we show the first measurements of upper tropospheric methanol profiles within aged fire plumes from the space-borne infrared spectrometer ACE-FTS. A detailed study of the sensitivity of the methanol retrieval, including random and systematic contributions, implies that the total error is about $20 \%$ at the maximum of the profile in the case of enhanced profiles measured inside polluted air masses and the profile is reliable from 8.5 to $16.5 \mathrm{~km}$. We report methanol vmr values higher than 4000 pptv for occultations measured from the tropics to mid-latitudes during October 2004. The correlation between upper tropospheric carbon monoxide and methanol is stronger in polluted air masses than in the background case. The upper tropospheric enhancement ratio with respect to CO deduced from ACE-FTS measurements inside aged biomass burning plumes agrees well with the ratio measured in the free troposphere (up to $12 \mathrm{~km}$ ) by recent aircraft measurements.

The ability of the ACE-FTS to measure methanol profiles in the UTLS (in the case of pollution events here) will lead to further scientific studies. Extending these capabilities to background methanol measurements will allow global mapping of methanol, the second most abundant organic species in the troposphere after methane, and will give better constraints to models used to derive estimates of the global methanol budget.

Acknowledgements. Funding for ACE is provided by the Canadian Space Agency and the Natural Sciences and Engineering Research Council (NSERC) of Canada. Support was also provided by the NSERC-Bomem-CSA-MSC Industrial Research Chair in Fourier Transform Spectroscopy.

Edited by: T. Röckmann

\section{References}

Andreae, M. O. and Merlet, P.: Emission of trace gases and aerosols from biomass burning, Global Biogeochem. Cycles, 15, 955966, 2001.

Bernath, P. F., McElroy, C. T., Abrams, M. C., Boone, C. D., Butler, M., Camy-Peyret, C., Carleer, M., Clerbaux, C., Coheur, P.-F., Colin, R., DeCola, P., DeMazière, M., Drummond, J. R., Dufour, D., Evans, W. F. J., Fast, H., Fussen, D., Gilbert, K., Jennings, D. E., Llewellyn, E. J., Lowe, R. P., Mahieu, E., McConnell, J. C., McHugh, M., McLeod, S. D., Michaud, R., Midwinter, C., Nassar, R., Nichitiu, F., Nowlan, C., Rinsland, C. P., Rochon, Y. J., Rowlands, N., Semeniuk, K., Simon, P., Skelton, R., Sloan, J. J., Soucy, M.-A., Strong, K., Tremblay, P., Turnbull, D., Walker, K. A., Walkty, I., Wardle, D. A., Wehrle, V., Zander, R., and Zou, J.: Atmospheric Chemistry Experiment (ACE): mission overview, Geophys. Res. Lett., 32, L15S01, doi:10.1029/2005GL022386, 2005.

Boone, C. D., Nassar, R., Walker, W. A., Rochon, Y., McLeod, S. D., Rinsland, C. P., and Bernath, P. F.: Retrievals for the Atmospheric Chemistry Experiment Fourier Transform Spectrometer, Appl. Opt., 44, 7218-7231, 2005.

Christian, T. J., Kleiss B., Yokelson, R. J., Holzinger, R., Crutzen, P. J., Hao, W. M., Saharjo, B. H., and Ward, D. E.: Comprehensive laboratory measurements of biomass-burning emissions: 1. Emissions from Indonesian, African and other fuels, J. Geophys. Res., 108(D23), 4719, doi:10.1029/2003JD003704, 2003.

Crutzen, P. J. and Andreae, M. O.: Biomass burning in the tropics: Impact on atmospheric chemistry and biogeochemical cycles, Science, 250, 1669-1678, 1990.

Galbally, I. E. and Kirstine, W.: The production of methanol by flowering plants and the global cycle of methanol, J. Atmos. Chem., 43, 195-229, 2002.

Goode, J. G., Yokelson, R. J., Ward, D. E., Susott, R. A., Babbitt, R. E., Davies, M. A., and Hao, W. M.: Measurements of excess $\mathrm{O}_{3}, \mathrm{CO}_{2}, \mathrm{CO}, \mathrm{CH}_{4}, \mathrm{C}_{2} \mathrm{H}_{4}, \mathrm{C}_{2} \mathrm{H}_{2}, \mathrm{HCN}, \mathrm{NO}, \mathrm{NH}_{3}$, $\mathrm{HCOOH}, \mathrm{CH}_{3} \mathrm{COOH}, \mathrm{HCHO}$, and $\mathrm{CH}_{3} \mathrm{OH}$ in 1997 Alaskan biomass burning plumes by Airborne Fourier transform infrared spectroscopy (AFTIR), J. Geophys. Res., 105(D17), 22 147$22166,2000$.

Hao, W. M. and Liu, M.-H.: Spatial and temporal distribution of tropical biomass burning, Global Biogeochem. Cycles, 8, 495503, 1994. 
Heikes, B. G., Chang, W., Pilson, M. E. Q., Swift, E., Singh, H. B., Guenther, A., Jacob, D. J., Field, B. D., Fall, R., Riemer, D., and Brand, L.: Atmospheric methanol budget and ocean implication, Global Biogeochem. Cycles, 16(4), 1133, doi:10.1029/2002GB001895, 2002.

Holzinger, R., Williams, J., Salisbury, G., Klüpfel, T., de Reus, M., Traub, M., Crutzen, P. J., and Lelieveld, J.: Oxygenated compounds in aged biomass burning plumes over Eastern Mediterranean: evidence of strong secondary production of methanol and acetone, Atmos. Chem. Phys., 5, 39-46, 2005,

http://www.atmos-chem-phys.net/5/39/2005/.

Jacob, D. J., Field, B. D., Li, Q., Blake, D. R., de Gouw, J., Warneke, C., Hansel, A., Wisthaler, A., Singh, H. B., and Guenther, A.: Global budget of methanol: constraints from atmospheric observations, J. Geophys. Res., 110, D08303, doi:10.1029/2004JD005172, 2005.

Levenberg, K.: A method for the solution of certain non-linear problems in least squares, Q. Appl. Math., 2, 164-168, 1944.

Lewis, A. C., Hopkins, J. R., Carpenter, L. J., Stanton, J., Read, K. A., and Pilling, M. J.: Sources and sinks of acetone, methanol, and acetaldehyde in North Atlantic marine air, Atmos. Chem. Phys., 5, 1963-1974, 2005, http://www.atmos-chem-phys.net/5/1963/2005/.

Marquardt, D. W.: An algorithm for least-squares estimation of nonlinear parameters, J. Soc. Appl. Math., 11(2), 431-441, 1963.

McHugh, M., McGill, B., Walker, K. A., Boone, C. D., Bernath, P. F., and Russell III, J. M.: Comparison of atmospheric retrievals from ACE and HALOE, Geophys. Res. Lett., 32, L15S10, doi:10.1029/2005GL022403, 2005.

Palmer, P. I., Jacob, D. J., Fiore, A. M., Martin, R. V., Chance, K., and Kurosu, T. P.: Mapping isoprene emissions over North America using formaldehyde column observation from space, J. Geophys. Res., 108(D6), 4180, doi:10.1029/2002JD002153, 2003.

Rinsland, C. P., Dufour, G., Boone, C. D., Bernath, P. F., and Chiou, L.: Atmospheric Chemistry Experiment (ACE) measurements of elevated Southern Hemisphere upper tropospheric CO, $\mathrm{C}_{2} \mathrm{H}_{6}, \mathrm{HCN}$, and $\mathrm{C}_{2} \mathrm{H}_{2}$ mixing ratios from biomass burning emissions and long-range transport, Geophys. Res. Lett., 32, L20803, doi:10.1029/2005GL024214, 2005a.

Rinsland, C. P., Paton-Walsh, C., Jones, N. B., Griffith, D. W. T., Goldman, A., Wood, S. W., Chiou, L., and Meier, A.: High Spectral Resolution Solar Absorption Measurements of Ethylene $\left(\mathrm{C}_{2} \mathrm{H}_{4}\right)$ in a Forest Fire Smoke Plume using HITRAN $2000 \mathrm{~Pa}-$ rameters: Tropospheric Vertical Profile Retrieval, J. Quant. Spectrosc. Radiat. Transfer, 96, 301-209, 2005b.

Rothman, L. S., Jacquemart, D., Barbe, A., Benner, D. C., Birk, M., Brown, L. R., Carleer, M. R., Chackerian Jr., C., Chance, K., Coudert, L. H., Dana, D., Devi, V. M., Flaud, J.-M., Gamache, R. R., Goldman, A., Hartmann, J.-M., Jucks, K. W., Maki, A. G., Mandin, J.-M., Massie, S. T., Orphal, J., Perrin, A., Rinsland, C. P., Smith, M. A. H., Tennyson, J., Tolchenov, R. N., Toth, R. A., Vander Auwera, J., Varanasi, P., and Wagner, G.: The HITRAN 2004 molecular spectroscopic database, J. Quant. Spectrosc. Radiat. Transfer, 96, 139-204, 2005.
Singh, H. B., Kanakidou, M., Crutzen, P. J., and Jacob, D. J.: High concentrations and photochemical fate of oxygenated hydrocarbons in the global troposphere, Nature, 378, 50-54, 1995.

Singh, H. B., Chen, Y., Tabazadeh, A., Fukui, Y., Bey, I., Yantosca, R., Jacob, D., Arnold, F., Wohlfrom, K., Atlas, E., Flocke, F., Blake, D., Blake, N., Heikes, B., Snow, J., Talbot, R., Gregory, G., Sachse, G., Vay, S., and Kondo, Y.: Distribution and fate of selected oxygenated organic species in the troposphere and lower stratosphere over the Atlantic, J. Geophys. Res., 105, 3795-3805, 2000.

Singh, H. B., Chen, Y., Staudt, A. C., Jacob, D. J., Blake, D. R., Heikes, B. G., and Snow, J.: Evidence from the South Pacific troposphere for large global abundances and sources of oxygenated organic compounds, Nature, 410, 1078-1081, 2001.

Singh, H. B., Salas, L. J., Chatfield, R. B., Czech, E., Fried, A., Walega, J., Evans, M. J., Field, B. D., Jacob, D. J., Blake, D., Heikes, B., Talbot, R., Sachse, G., Crawford, J. H., Avery, M. A., Sandholm, S., and Fuelberg, H.: Analysis of the atmospheric distribution, sources, and sinks of oxygenated volatile organic chemicals based on measurements aver the Pacific during TRACE-P, J. Geophys. Res., 109, D15S07, doi:10.1029/2003JD003883, 2004.

von Kuhlmann, R., Lawrence, M. G., Crutzen, P. J., and Rasch, P. J.: A model for studies of tropospheric ozone and nonmethane hydrocarbons: Model description and ozone results, J. Geophys. Res., 108(D9), 4294, doi:10.1029/2002JD002893, 2003a.

von Kuhlmann, R., Lawrence, M. G., Crutzen, P. J., and Rasch, P. J.: A model for studies of tropospheric ozone and nonmethane hydrocarbons: Model evaluation of ozone-related species, J. Geophys. Res., 108(D23), 4729, doi:10.1029/2002JD003348, 2003b.

Xu, L.-H., Lees, R. M., Wang, P., Brown, L. R., Kleiner, I., and Johns, J. W. C.: New assignments, line intensities, and HITRAN database for $\mathrm{CH}_{3} \mathrm{OH}$ at $10 \mu \mathrm{m}$, J. Mol. Spectrosc., 228, 453-470, 2004.

Yokelson, R. J., Goode, J. G., Ward, D. E., Susott, R. A., Babbitt, R. E., Wade, D. D., Bertschi, I., Griffith, D. W. T., and Hao, W. M.: Emissions of formaldehyde, acetic acid, methanol, and other trace gases from biomass fires in North Carolina measured by airborne Fourier transform infrared spectroscopy, J. Geophys. Res., 104(D23), 30 109-30 125, 1999.

Yokelson, R. J., Bertschi, I. T., Christian T. J., Hobbs, P. V., Ward, D. E., and Hao, W. M.: Trace gas measurements in nascent, aged, and cloud-processed smoke from African fires by airborne Fourier transform infrared spectroscopy (AFTIR), J. Geophys. Res., 108(D13), 8478, doi:10.1029/2002JD002322, 2003. 